\title{
Ophævelsen af \\ den gamle herredsforfatning på Vesterland Før og Amrum
}

En kongelig ordre af 1697 - dens årsager og følger

\author{
af VOLKERT F. FALTINGS
}

Frem til 1697 fulgte retsvæsenet og administrationen i de kongerigske enklaver Vesterland Før og Amrum regler i Jyske Lov og gamle sædvaner. Stor indflydelse havde en lokal bondeoverklasse. Efter 1660 havde dette harmoneret dårligt med normerne $\mathrm{i}$ den unge danske enevælde. Talrige misforhold $\mathrm{i}$ sagsbehandlingen på Før og Amrum forte endelig i 1697 til reformer, som gjorde en ende på nedarvede sædvaner og det lokale selvstyre. Dr. Volkert Faltings belyser her denne grundlæggende ændring og påviser, hvordan enevældens onsker om en mere professionel forvaltning satte sig spor også i enklaverne på de to øer langt fra København.

Artiklen er en forkortet gengivelse af den tysksprogede udgave i Nordfriesisches Jahrbuch 2001 s. 7-68. Oversættelse: Birgit Christensen, Vanløse.

\section{Indledning}

I ældre publikationer om øerne Før og Amrums historie ${ }^{1}$ støder man gentagne gange på den udtalelse, at Før Vesterherred og Amrum blev forvandlet til et kongerigsk dansk birk ${ }^{2}$ i 1697, og at herredsrådet, der havde tolv medlemmer, samtidig blev afsat og erstattet af 40 såkaldte gangfersmænd. Ocke Nerong tilføjer en bemærkning om, at denne omstrukturering først og fremmest er sket på foranledning af grønlandskommandøren Matz Peters, bedre kendt som »Lykkelige Matthies«, idet denne skal have indberettet til Kobenhavn, at der blandt de tolv rådmænd ikke var en eneste, der var i stand til selvstændigt at afsige en dom. ${ }^{3}$ Af hvilken primærkilde Nerong her har øst, fortier han. Tilsyneladende bygger alle senere forfattere på Nerong. Før ham er det kun Silds historieskriver Christian P. Hansen, der beretter, at det i 1697 på Vesterland Før blev forordnet, at der skulle være 42 [det korrekte er 40] gangfersmænd i stedet for de tolv rådmænd. ${ }^{4}$ Men 
Hansen er ofte ret upålidelig med sine oplysninger, og desværre oplyser heller ikke han om sin kilde.

Indtil 1864 var Før Vesterherred og Amrum kongerigske enklaver. I de fleste forvaltningssager på mellemniveau sorterede de under Ribe amt og på rigsniveau under Danske Kancelli i København. Man kunne altså formode, at der i hhv. Ribe amtsarkiv og Danske Kancelli, måtte findes akter om de nævnte hændelser i og omkring året 1697. Denne formodning har vist sig rigtig. Det viste sig, at der er bevaret en officiel korrespondance mellem den daværende stiftamtmand $i$ Ribe Franz Eberhard von Speckhan og Danske Kancelli, som belyser begivenhederne ret godt, og som berører anledningen til disse forandringer, der skulle blive så gennemgribende for den offentlige forvaltning i Før Vesterherred og Amrum. ${ }^{5}$ Von Speckhan fremtræder i disse papirer som skolet forvaltningsembedsmand efter den enevældige statsforvaltnings principper. Kilderne viser også, at Matz Peters faktisk var indblandet $\mathbf{i}$ forløbet, så vidt man kan se endog den, der udløste begivenhederne. Det centrale aktstykke i denne korrespondance er et »memoriale« (en betænkning), forfattet af stiftamtmanden

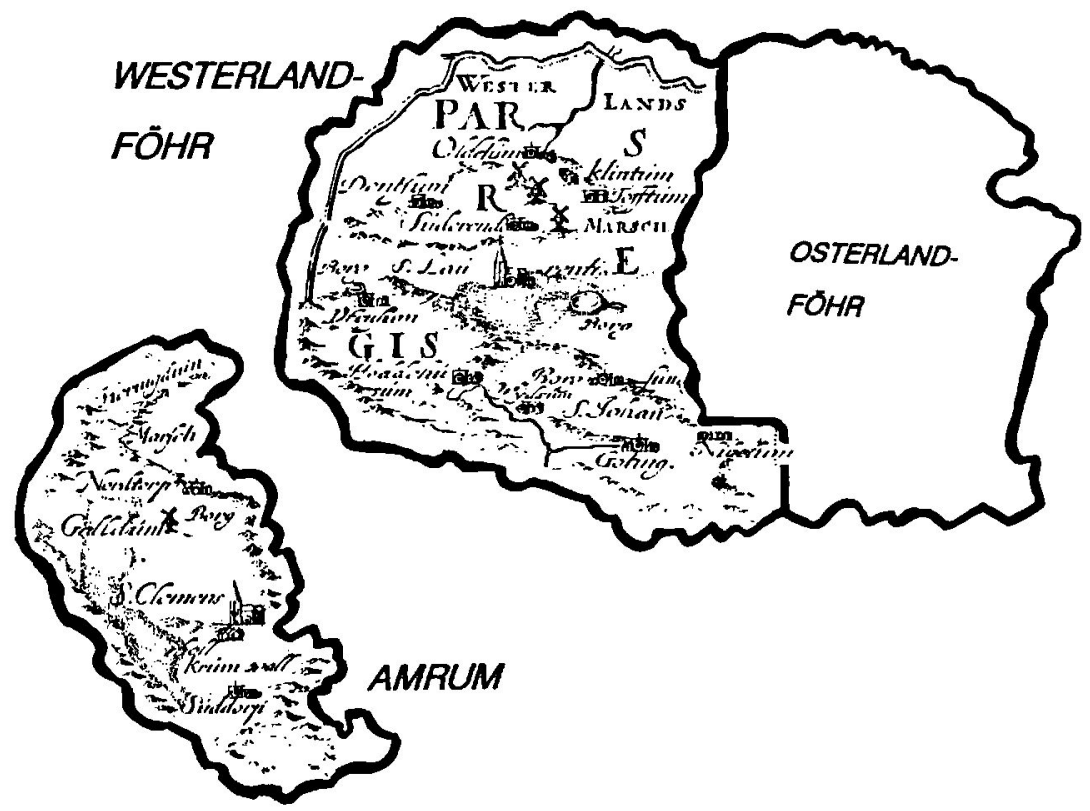

De kongerigske enklaver Vesterland For og Amrum. Kort V. Faltings, efter Danckwerth: Newe Landesbeschreibung 1652. 
i $1696 .^{6}$ Heri kommer stiftamtmanden udførligt ind på de dårlige tilstande i jurisdiktionen på Vesterland Før og Amrum, og han ender med at forelægge Danske Kancelli nogle forslag til en reform. Den kongelige ordre af 1697 er udtryk for den reaktion, som betænkningen fremkaldte i kancelliet, og som førte til afskaffelsen af rådskollegiet med 12 medlemmer og dermed begyndelsen til enden for den herredsforfatning på Vesterland Før og Amrum, der havde eksisteret fra gammel tid. ${ }^{7}$

Det lykkedes ikke at finde den ovennævnte skrivelse fra Matz Peters og heller ikke at påvise eksistensen af den. Ved studiet af denne korrespondance får man det bestemte indtryk, at det mystiske brev fra Matz Peters til kongen eller Danske Kancelli i virkeligheden aldrig har eksisteret, men at det snarere har været stiftamtmanden i Ribe, som startede sagen. I sit memoriale indberetter han faktisk til Kobenhavn, at det ikke kunne attesteres, at de 12 rådmænd i Vesterherred havde nogle særlige kvalifikationer til deres embede, og herved refererer han bl.a. til Matz. Det ser ud til, at Matz i sit klageskrift til amtmanden har givet udtryk for noget lignende, selv om kilderne ikke oplyser noget nøjere om det.

I det følgende vil jeg se på baggrunden for og virkningerne af Speckhans memoriale, der førte til afskaffelse af den gamle herredsforfatning. Samtidig vil jeg forsøge at afklare spørgsmålet om, hvilke formål Matz Peters kan have haft med den klage over de retslige tilstande i Vesterherred, der fik så vidtrækkende følger.

\section{De kongerigsk-danske enklaver Vesterland Før og Amrum efter 1660}

Da kong Frederik 3. den 10. januar 1661 underskrev den såkaldte suverænitetsakt, ændrede det grundlæggende de politiske forhold i Danmark. Det hidtil eksisterende danske valgmonarki blev forvandlet til et arvemonarki, og adelen, som indtil da afgørende havde præget de daglige politiske forretninger i rigsrådet, mistede sin magt. Bogstaveligt fra den ene dag til den anden var kongen blevet enevældig. Man kunne nu målbevidst iværksætte både den længe tiltrængte reform af forvaltningsapparatet, som var i en dårlig forfatning, og saneringen af statshusholdningen, som nærmest lå i ruiner. Men disse høje mål kunne kun virkeliggøres ved, at en stor del af krongodserne og de kongelige regaler blev afhændet eller overladt de talrige kreditorer 


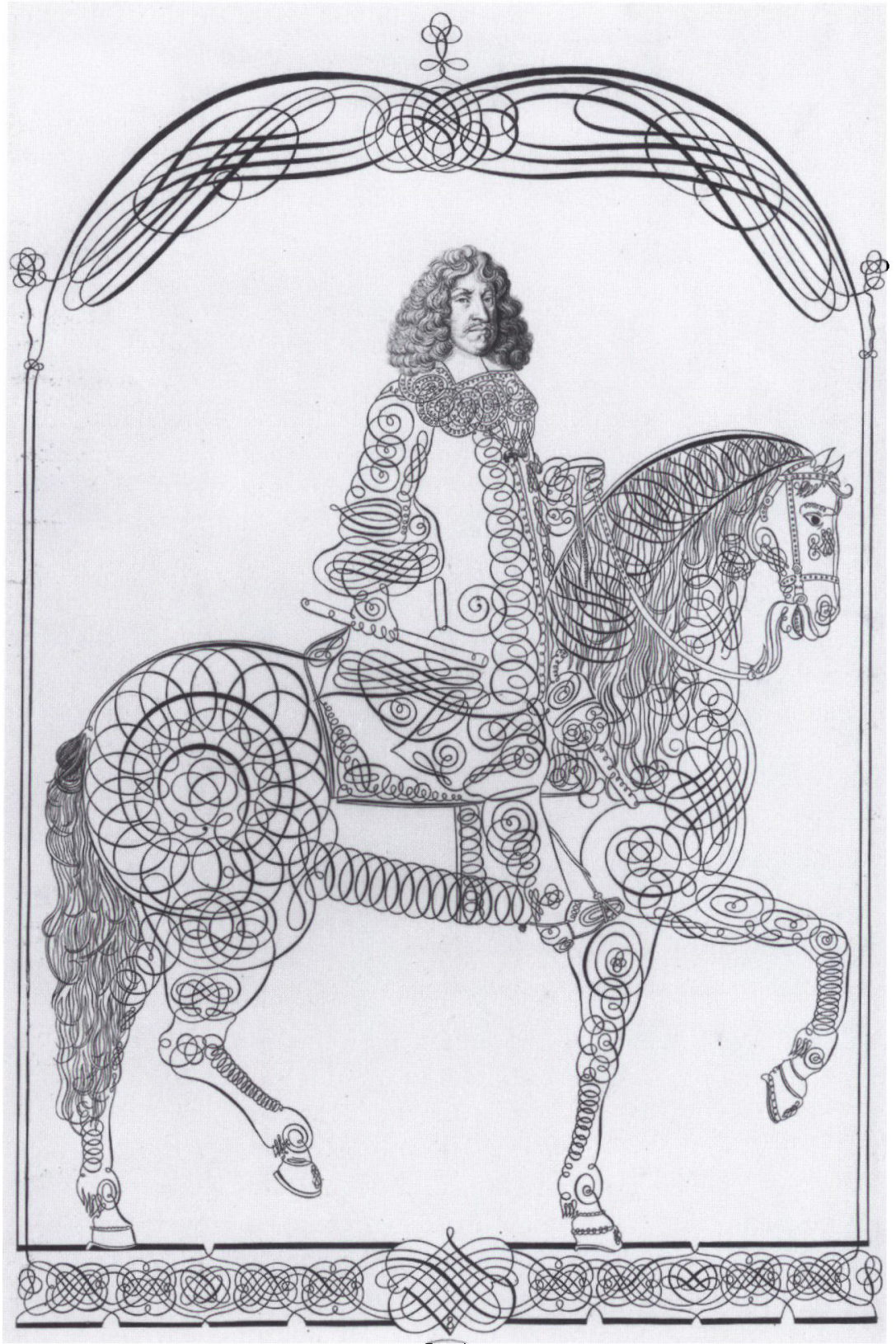

Kong Frederik 3. Rytterportræt $i$ Kongeloven $i$ udgaven fra 1709. Foto: Det Kongelige Bibliotek. 
som pant - en handling, som ligner intet mindre end en heldig tilsløring af en truende statsbankerot.

Disse afgørende forandringer i stat og samfund blev i den allerførste tid kun i meget begrænset grad følelige for de kongelige undersåtter i den kongerigske enklave Vesterland Før og Amrum. ${ }^{8}$ Men helt sikkert har de mærket det øgede skatte- og afgiftstryk på grund af statsfinansernes sørgelige tilstand. $\mathrm{Og}$ i alt fald har nyheden om at kongen den 25. maj 1658 havde forlenet den daværende generalløjtnant og senere rigsfeltherre og greve Hans Schack (*29.10.1609 i Undevad i Angel, + 27.2.1676 i København) ${ }^{9}$ med Riberhus len, det senere Ribe amt, hvorunder som bekendt også Vesterherred hørte, ikke været ligegyldig for dem. Efter den lykkeligt overståede anden Karl Gustav-krig fik den karismatiske hærfører og succesrige forsvarer af Kobenhavn den 31. januar 1661 overdraget lenet på livstid, oven i købet afgiftsfrit. Man kunne formode, at der bag denne generose handling stod en taknemmelig monark, der ville vise sig erkendtlig over for en velfortjent feltherre. Men det er ikke tilfældet. Tværtimod var der tale om at kronen her indløste en hel række kontraktlige tilsagn, som man havde indgået med Schack ved krigsudbruddet i 1658 for at gøre det lettere for ham at beslutte sig til at træde i kronens tjeneste, og Hans Schack, der på den tid sad i en sikker stilling som fæstningskommandant i Hamborg, var helt klar over sin pris! Hans krav blev større $i$ takt med, at Frederik 3.s vanskeligheder tog til. ${ }^{10}$

Da kronen til sidst begyndte at afhænde betydelige dele af krongodset for at forhindre en truende statsbankerot (jfr. ovfr.), købte Schack den 5. september 1661 godset Møgeltønderhus, sit fremtidige stamsæde, og de dertil hørende rettigheder og indkomster. Den opfattelse, der ofte er blevet fremført, at købet også omfattede Vesterland Før og Amrum, er forkert eller i det mindste en misforståelse. Tværtimod erhvervede han ved denne lejlighed kun den årlige skatteindkomst derfra på 80 tonder hartkorn ${ }^{11}$ samt forskellige andre kongelige rettigheder (regaler), deriblandt jagt- og strandretten og den formentlig ret indbringende ret til det kongelige østersfiskeri i Vadehavet mellem Rømø og Før, ${ }^{12}$ kort tid derefter 1 . november 1661 også patronatsretten $\mathrm{i}$ Vesterherred med kirkens andel af korn- og kvægtienden samt indkomsterne af kirkens fæstegods. ${ }^{13}$ Derudover fik han retten til opkøb af de okser, der var opdrættet i området - i det mindste i Vesterherred, men formodentlig ligeledes $i$ andre dele af hans område; her 


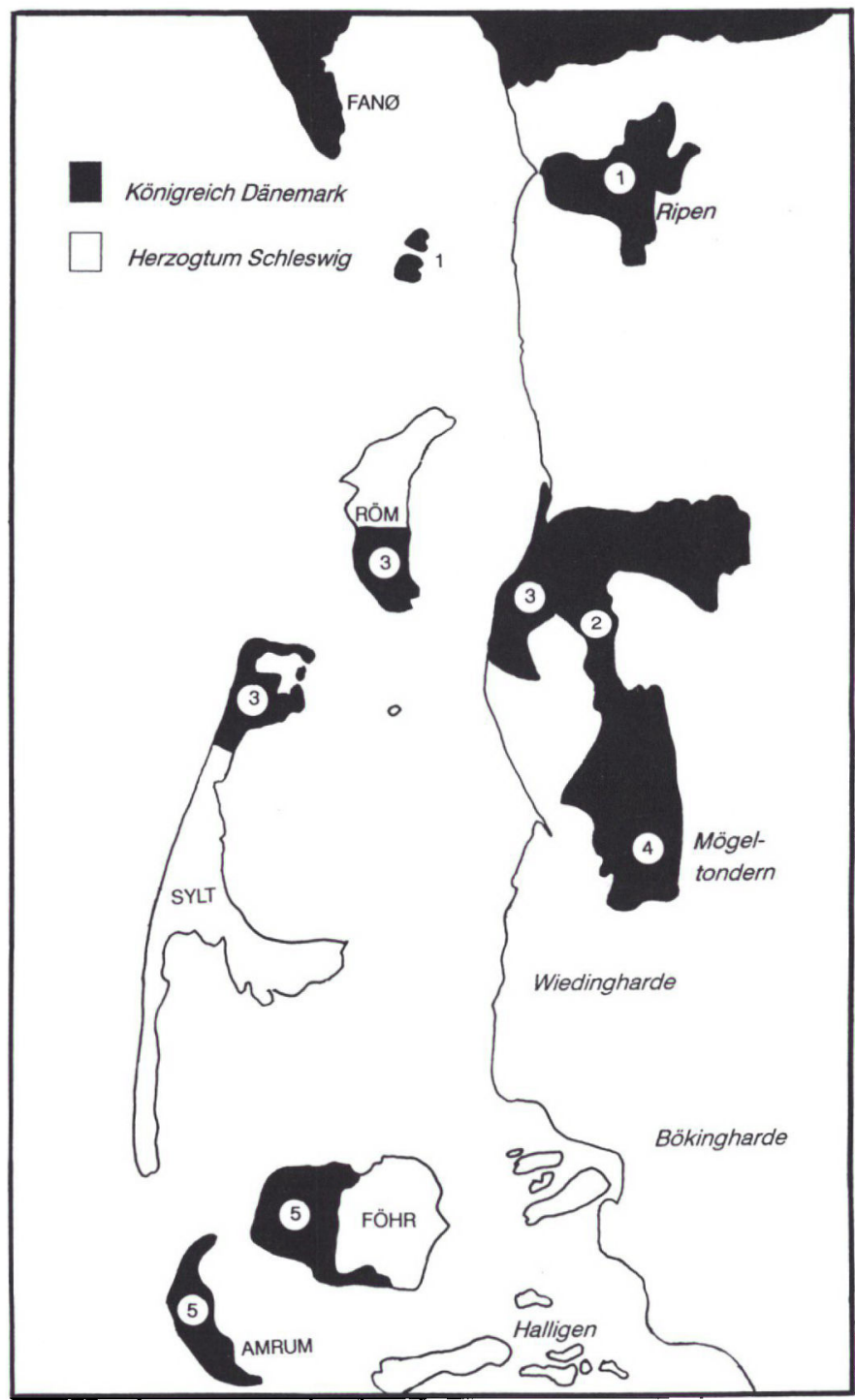

De kongerigske danske enklaver $i$ Slesvig omkring 1700.

1. Riberhus birk med Mano

2. Lo herred

3. Ballum birk med List på Sild og Rømø sonderland

4. Mogcltonder birk med grevskabet Schackenborg

5. Vesterlandfor og Amrum Kort: V. Faltings.

fungerede landfogeden som opkøber for ham. Det samme gjaldt tydeligvis handlen med dun og fjer. ${ }^{14}$

Fra 5. september 1661 havde møllerne i Vesterherred også tilhørt Schack, men dem overlod han 20. marts 1665 til de lokale bønder på den betingelse, at de skulle overtage den gæld, der var i møllerne, 
medens den indtil da betalte forpagtningsafgift af mollerne bortfaldt. Allerede 22. juli 1662 havde han ophævet den mølletvang, der åbenbart gjaldt i Vesterherred. Formodentlig har indkomsterne af mølleskylden ikke dækket de løbende vedligeholdelsesomkostninger ved møllebygningerne og mølleteknikken eller i det mindste ikke dækket dem helt. Men også bønderne ser ud til at have fået lignende udligningsproblemer, for den 22. februar 1669 klager møllerne på tinge over, at herredet bebyrder dem med for høje afgifter på møllerne (DP 2264). Af den grund synes bønderne snart efter at have solgt møllerne, efter at de dog først havde forpagtet dem til lokale interessenter. Mølleregalet beholdt Schack imidlertid, og møllerne måtte lige som tidligere betale en årlig skat. ${ }^{15}$

Hvad angår datidens skattepligt i Vesterherred, blev de land- og tjenestepenge, der indtil da havde skullet erlægges hver måned eller hvert kvartal, fastsat til et samlet årligt beløb på 1600 rigsdaler, som skulle betales $i$ to lige store dele til terminerne 31 . maj og 31 . oktober. Hertil kom desuden årligt 100 rigsdaler i kontribution samt frøkenskatten, som kongen opkrævede, når han skulle udruste en af sine døtre med et udstyr ved hendes giftermål. Yderligere opkrævede kongen i alt fald en tid - en årlig særskat af søfolkene, den såkaldte botsmannsschatt (dvs. bådsmandsskat, DP 1825), som formodentlig tjente til udrustning af mandskabet $i$ kongens flåde. Senere slog det kongelige rentekammer de forskelligartede skatter og afgifter sammen til en fast sum på 1700 rigsdaler. Art og omfang af denne årlige kontribution forblev derefter - bortset fra forhøjelser af og til - bevaret uforandret til ind i preussisk tid.

Derudover var tingretten i birkerne Lustrup, Møgeltønder og Ballum i 1661 tilfaldet Schack - og naturligvis de indtægter, der fulgte dermed. Vesterland Før og Amrum har historikerne ikke nævnt i denne sammenhæng, men skødet af 5 . september 1661 (jfr. note 13) skal utvivlsomt fortolkes sådan, at Schack fra da af også udøvede tingretten i Vesterherred, eftersom godsforvalteren og andre underordnede embedsmænd fra Schacks administration i Møgeltønder i den følgende tid optrådte på Vesterherreds ting som rigsfeltherrens befuldmægtigede og derved $i$ enkelttilfælde greb ind i den lokale administration og jurisdiktion, hvad f.eks. tingprotokollerne fra Før Vesterherred og Amrum 1658-71 flere gange giver vidnesbyrd om for tiden fra efteråret 1661 fremefter. Kort efter, at Hans Schack, der allerede i 1671 var blevet ophøjet til greve, var død, blev godset Møgeltønder ophøjet til 


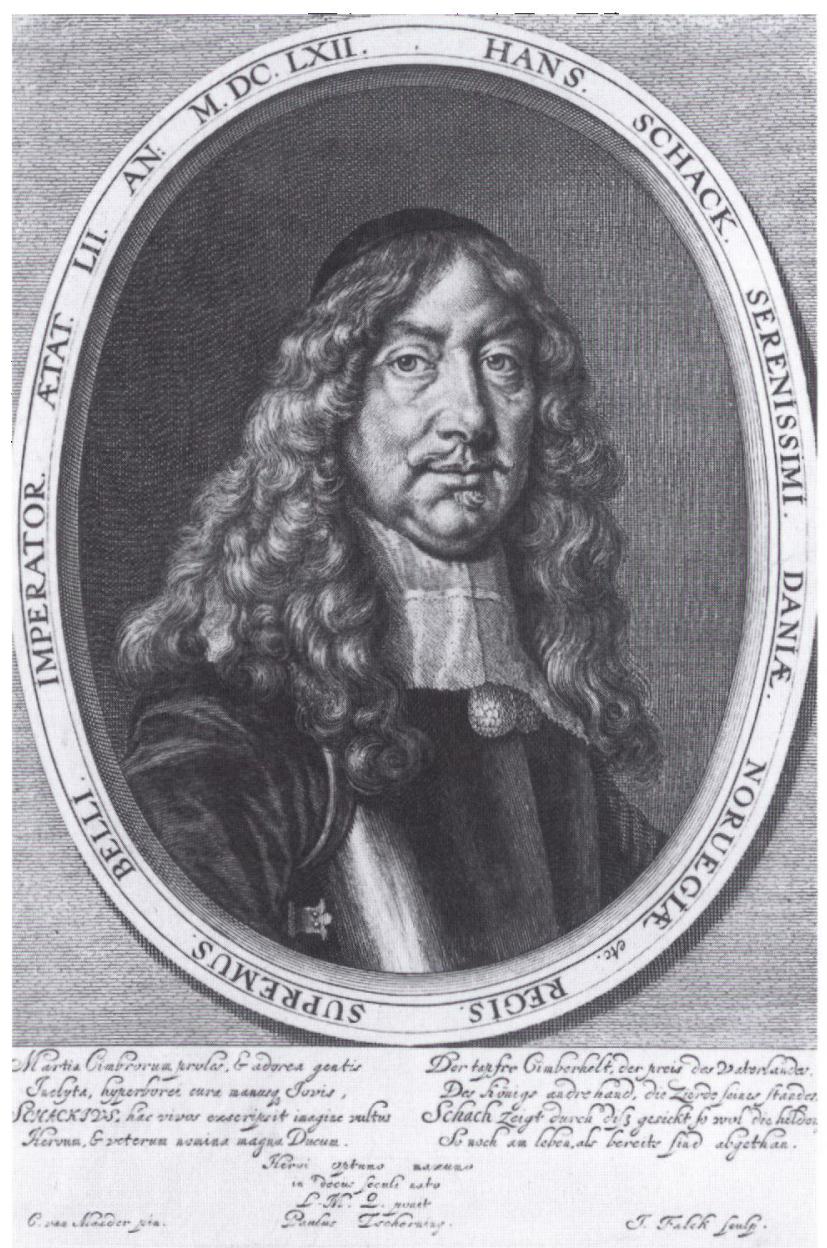

Rigsfeltherre Hans Schack. Stik af J. Falck, 1662. Foto: Det Kongelige Bibliotek.

grevskab, og i oprettelsesbrevet af 23. juni 1676 anføres under det nyoprettede grevskab Schackenborgs indkomster ved siden af $j u s p a-$ tronatus udtrykkeligt også birkeretten over Vesterherred. ${ }^{16}$

Disse omstruktureringer, der for en stor del skete af hensyn til skatteopkrævning, forandrede Vesterherreds forhold til ovrigheden og private ejere $\mathrm{i}$ ikke uvæsentlig grad, og det var på ingen måde kun til fordel for herredet. Men herredets indre forhold og det offentlige liv, specielt Vesterherreds gamle herredsforfatning, blev i begyndelsen ikke berørt af dette. Herredets fornemste institution, tingforsamlin- 


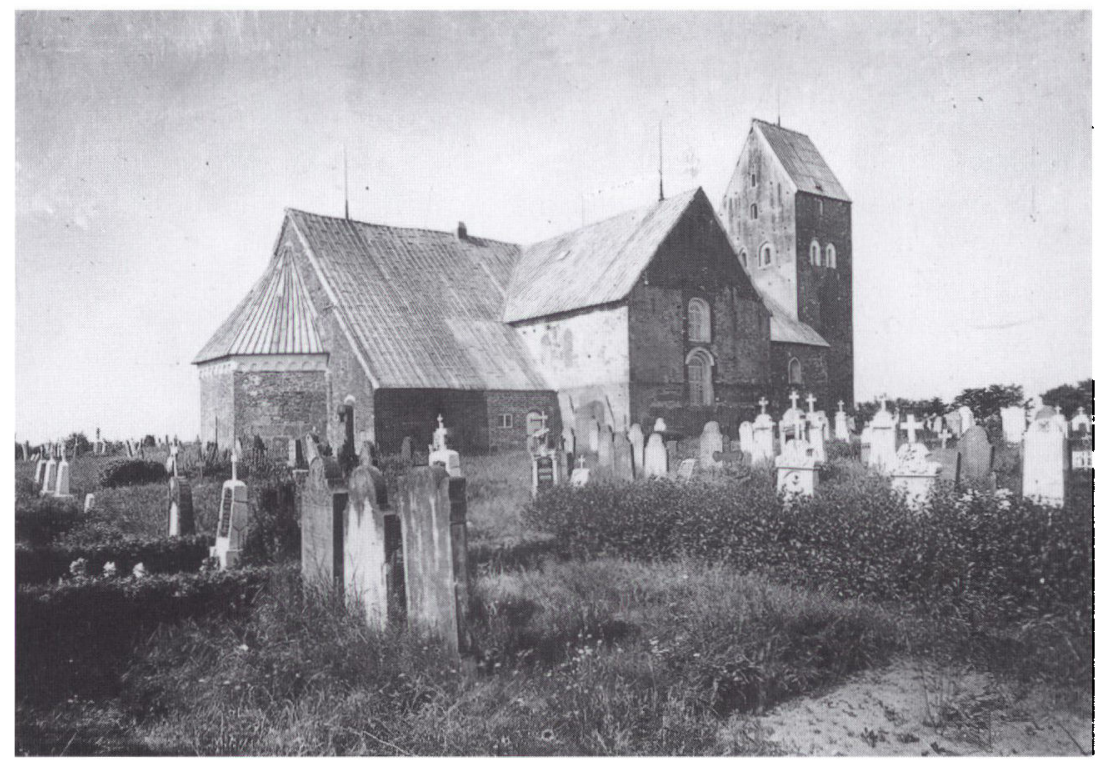

St. Laurentius kirke på Før. Foto o. 1900.

gen, mødtes stadig på traditionel vis under åben himmel. Muligvis skete det ved eller i umiddelbar nærhed af St. Laurentii kirke; optegnelser i tingprotokollen 1658-71 tyder på dette. At mødet endnu på den tid faktisk fandt sted udendørs, fremgår af en tilfældig sag, som er overleveret $\mathrm{i}$ anden sammenhæng. Da den velhavende handelsmand Torlck Rickmers (1595-1681) fra Oevenum på Østerland Før den 29. november 1664 på tinge på en noget friskfyragtig måde havde begæret, at rådet på Vesterland skulle fuldbyrde en revisionsdom, der var afsagt til hans fordel og i den forbindelse havde undladt at vise landfoged Jap Peters (om ham se ndfr.) og de tilstedeværende rådmænd den nødvendige ærbødighed ved at tage sin hue af, rev den fortørnede landfoged den uden videre af ham, så at Torlck fornærmet råbte, at en gammel mand da vel måtte have lov til at beholde huen på, når der blæste en kold østenvind (DP 1551). Et andet sted bevidner to Steveningsmänner (stævningsmænd) "up ding in deß landtfagetz behüsinge“ (på tinge i landfogedens bolig) (DP 1763), at den anklagede var lovmæssigt og rettidigt stævnet, men det drejer sig her om den eneste indførsel i tingbogen fra den 28. november 1665, og den egentlige tingforsamling ser ud til at være faldet bort den dag muligvis på grund af vejret. Landfoged Jap Peters' hus i den østlige 
del af Oldsum var bestemt ikke det sted, hvor Vesterherreds ting permanent trådte sammen. At der til sidst slet ikke var noget fast tingsted, kan ligeledes så godt som udelukkes, da en sådan ordning ville have været helt i modstrid med de gamle retsskikke i det øvrige danske rige og ikke mindst lovbestemmelserne dér.

Det er først senere, da den tiltagende brug af skriftlige dokumenter gjorde det tvingende nødvendigt at være et sted, hvor man var uafhængig af vejret, at tinget mødes under tag. Sikre efterretninger om, hvornår og hvor det kan være sket, får man ganske vist ikke før 1746. På den tid var tinglokalet $\mathrm{i}$ huset hos møllerenken Anna Martens (1713-1781), der lå, hvor man vestfra kommer ind i landsbyen Nieblum, nu Kertelheinallee 16; huset hørte dengang endnu til Goting ejerlav. Da hun i august 1746 flyttede til Nieblum, bekendtgjorde den daværende birkefoged Marcus Matthiesen den 2. august 1746 offentligt for alle indbyggerne på Vesterland Før og Amrum, at tingretten også derefter ville træde sammen hos Anna Martens, nu i hendes nye bolig i Nieblum. ${ }^{17}$ Det var forst $i$ et hus, som ikke mere eksisterer, men som lå midt $i$ landsbyen ved bygaden, og senest fra 1750 var det i nabobygningen i den nuværende Jens-Jacob-Eschels-Straße 27, et hus, der tilhørte hendes anden mand Boye Bahnsen. Dér mødtes birkeretten for Før Vesterherred og Amrum - bortset fra en kortvarig afbrydelse i 1807 - indtil den blev oplost den 31. december $1867 . .^{18}$

Retsvæsen og administration var dengang ikke adskilte anliggender. Kommunale herredsanliggender og retssager behandledes på samme ting - sådan var det overalt $i$ kongeriget Danmark og hertugdømmet Slesvig. Jyske Lov fra 1241 dannede det retslige grundlag, i 1600-årene i Ekenbergs oversættelse til nedertysk fra 1593 eller 2. oplag fra 1603. Derudover gjaldt i Vesterherred forskellige kongelige recesser samt lokale love og vedtægter, der ofte ikke var nedskrevne, men hvis gyldighed var hævet over enhver tvivl. ${ }^{19}$ I flere tilfælde har man benyttet f.eks. »olden landsgebruk« (gammel skik i landet, DP 1384) eller en "landrecht van olders her (landslov fra gammel tid, DP 2775), altså en eller anden ikke nærmere betegnet sædvaneret.

Landfogeden ledede mødet på tinge som kongens repræsentant, senere som grev Schacks, og overvågede, at alt forløb korrekt, passede på, at de vedtagne beslutninger og domme blev fort ordentligt ud i livet, men udøvede ellers ikke nogen direkte indflydelse på arbejdet med at nå til retslige afgørelser eller på domsafsigelserne. Dette påhvilede forskellige dømmende forsamlinger: I tyveri- og røverisager 
Titelblad til mudske Lowbock" 1593 i Blasius Ekenbergers plattyske oversættelse.

Foto: Schleswig-Holsteinische Landesbibliothek, Kiel.

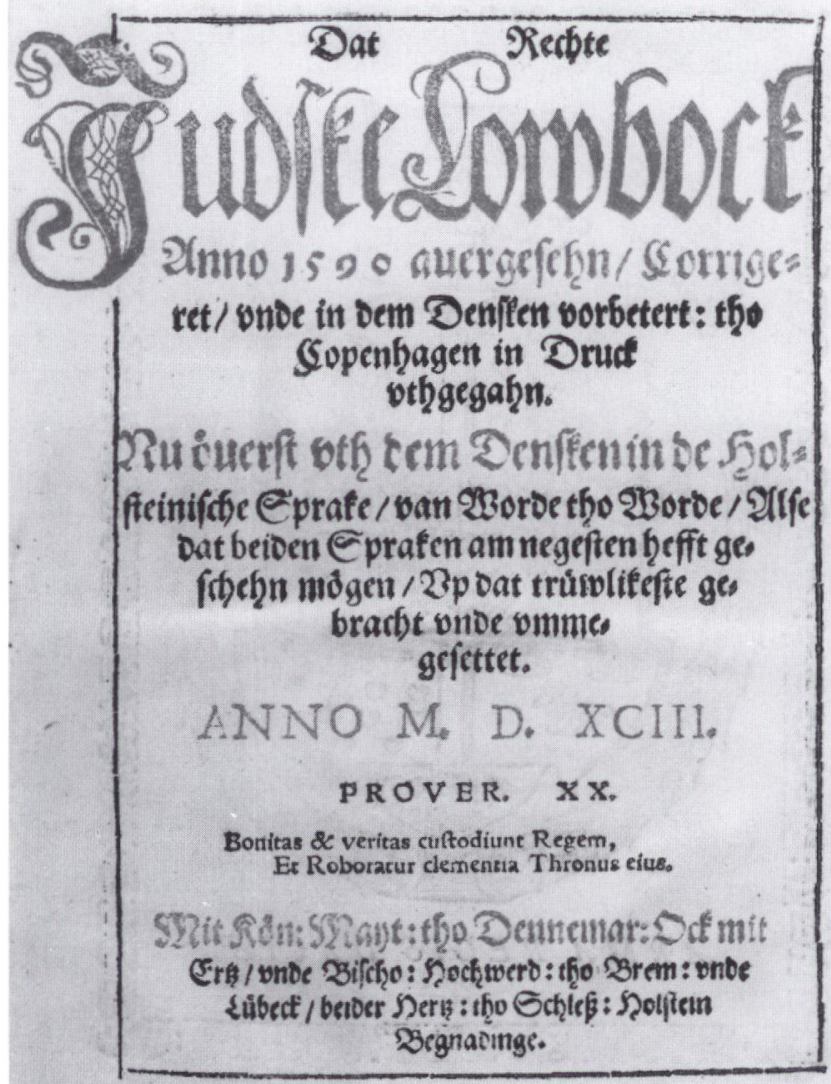

svor f.eks. Ransneffninge (ransnævninge), en forsamling på otte medlemmer, som blev nyudnævnt og taget $i$ ed hvert år på årets første tingdag; Sandmänner (sandemænd), hvoraf der også var otte, men som var udnævnt på livstid, svor i tilfælde af svære voldshandlinger. Både ransnævningene og sandemændene tog sig forst af en retssag, når en rådsdom formelt havde fastslået deres beføjelse (jfr. f.eks. DP 496, 1117, 2306).

Men i den store mængde af foreliggende retssager dømte de 12 rådmænd. Rådet, der oftest mødtes og afsagde domme uden for tinget, bestod af særligt ansete bønder fra Vesterherred, som på bøndernes 
forslag blev kaldet på livstid af øvrigheden. Derudover kunne man i ganske bestemte tilfælde inddrage yderligere personer $\mathrm{i}$ arbejdet; de blev udnævnt specielt efter behov. Vesterherreds egentlige kommunale repræsentation blev varetaget af de derboende Hardesbunden (herredsbønder), de frie og selvstændige grundejere, som var ejere af et helt Bohl (bol). Selv om det nøjagtige antal af bønder ikke er nævnt nogen steder, er der dog nogle holdepunkter. I tingprotokollerne 1658-71 er der mellem den 25. maj 1658 og 25. maj 1659 anført over 110 forskellige tingsvidner. Da kun herredsbønderne kunne beskikkes som vidner på tinge, kan vi regne med dette antal som et sikkert mindstetal. I virkeligheden var tallet nok væsentligt højere. Administrative afgørelser, for så vidt de hørte under herredets kompetence og det gjaldt især økonomiske sager og skattesager - kunne kun træffes med udtrykkelig billigelse af bønder, der var til stede på tinge. I særlige tilfælde dannede bønderne derudover et udvalg på 12 »Hardeslüden« (herredsfolk, DP 246), som repræsenterede bøndernes og dermed hele herredets interesser over for tredjemand..$^{20}$

Skatterne til landsherren og de øvrige afgifter blev opkrævet af 40 Gangfersmänner (gangfersmænd), som hver stod i spidsen for et gangfer (skattedistrikt). Forinden havde 24 Ummarkungsmänner (hegnssynsmænd) takseret samtlige skattepligtige aktiver i herredet, og nogle af dem, Rechensmänner (regnskabsmændene), fordelte den udregnede skattesum på gangferne, hvorefter fordelingen af skatten på de skattepligtige personer kunne fastlægges. Derefter hørte det til landfogedens opgaver at aflevere de indsamlede penge rettidigt på Ribe amtstue. Landfogeden optrådte her som statsmagtens forlængede arm, idet han repræsenterede kongens eller Schacks interesser over for herredets indbyggere og deres repræsentanter, bønderne. Også forvaltningen af de øvrige kongelige regaler og besiddelser, f.eks. møllerne og opkøb af okser, der var opdrættet i området, blev varetaget af ham. ${ }^{21}$

Disse forhold ændrede sig ikke, da landfoged Jap Peters efter Hans Schacks død blev afløst den 9. oktober 1676 af Joachim Lütken, der var født i Lauenburg. Det var første gang, landfogedembedet blev besat af en udefra kommende, der ikke stammede fra kredsen af lokale bønder. Muligvis bragte han dog en administrativ uddannelse med sig. I øvrigt forblev Vesterland Førs og Amrums overleverede retsordning uberørt i kraft. Det gjaldt da Hans Schacks efterfølger, lensgreve Otto Diedrich Schack i begyndelsen af 1683 igen måtte afstå sine ret- 
Titelblad til

Danske Lov $i$ trykket fra

1683. Foto:

Det Kongelige Bibliotek.

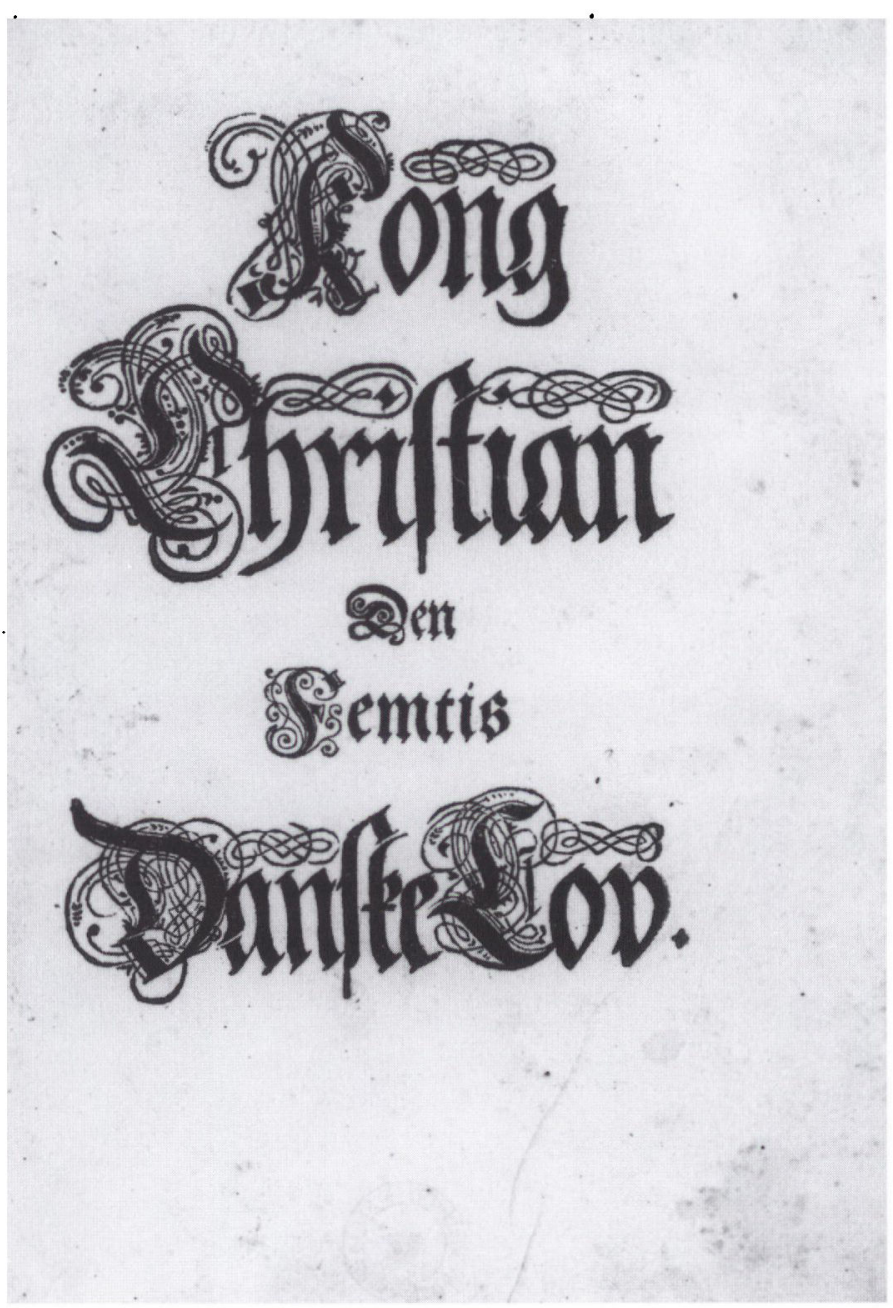

tigheder på Vesterland Før og Amrum samt dem på Listland på Sild og den sydlige del af Rømø til kronen, som atter lagde de to områder under Ribe amt. I den forbindelse gav kronen ifølge skrivelse fra det kongelige rentekammer af den 3. januar $1683^{22}$ til gengæld afkald på udligning af gamle og nye fordringer på lensgreven. Det er påfaldende, at den kort tid efter udstedte Danske Lov, som i september 1683 fik retskraft i hele kongeriget, $i$ begyndelsen ikke kom $i$ anvendelse på Vesterland Før og Amrum. Måske var fastholdelsen ved Jyske Lov 
i dette tilfælde oven i købet godkendt af kongen, da den danske tekst i den nye lov næppe kan have været forståelig for de overvejende frisiske indbyggere $i$ Vesterherred og heller ikke for de fleste medlemmer af deres råd og andre dømmende forsamlinger. Selv om de kilder, der er brugt til nærværende arbejde, tier om den egentlige årsag til, at man holdt fast ved Jyske Lov, kan man dog for de første år efter 1683 regne med, at de kongerigske enklaver Vesterland Før og Amrum på dette punkt har fulgt praksis i de fleste slesvigske distrikter i nærheden, hvor Jyske Lov fortsat benyttedes i såvel den kongelige som den hertugelige del. Først da stiftamtmanden i Ribe i 1697 begyndte at tage forholdsregler til at forbedre retsforholdene på Vesterland Før og Amrum, førte det til, at Danske Lov af 1683 endelig også fik sit gennembrud i Vesterherred.

\section{Afskaffelsen af den gamle herredsforfatning Arsager}

Selv om Hans Schack, der var en ivrig forkæmper for enevældens statsopfattelse og merkantilismen, forvaltede både sine egne godser og Ribe amt med omtanke og handlekraft, blev hans - på ingen måde uegennyttige - bestræbelser på at fremme landets vel og øge effektiviteten i sin administration den ene gang efter den anden modarbejdet af den lokale befolkning. Mange af Schacks anordninger og forbud blev jævnligt ringeagtet af dem, de vedrørte. Det var næsten almindelig skik. Det gælder f.eks. forbuddet mod at fiske østers i hans område ${ }^{23}$ og mod at lade marksten, som der var hårdt brug for til at udbedre stendiget mellem Utersum og Dunsum på Vesterland Før, køre væk fra forstranden til eget brug. ${ }^{24} \mathrm{Og}$ selv om Schack gentagne gange eftertrykkeligt gjorde indbyggerne i Vesterherred opmærksomme på forbuddet mod udførsel af okser og mod harejagt, rettede man sig ligeledes kun i ringe grad efter disse anordninger. Desuden kan man tvivle på, om det forbud mod at skære marehalm, der var udstedt af hensyn til kyst- og klitsikringen (DP 2120, 2546), kunne sættes effektivt igennem, til trods for, at der blev truet med korporlig straf. Netop på Amrum var der ikke så få "småfolk ", der erhvervede sig en ringe, men uundværlig biindtægt ved at forarbejde marehalm til reb eller måtter. Åbenbart gjaldt også her den kendte russiske talemåde »Der er højt til himlen, og zaren er langt væk!«

Da Schack under krigen mod svenskerne (1658-60) indgik overens- 
komst med officererne for de plyndrende kejserlige hjælpetropper om en forholdsvis høj kontribution for Vesterland Før og Amrum, formodentlig for at forebygge noget værre, nægtede talrige bønder i Vesterherred under deres modige talsmand Rörd Olufs (ca. 1615-1694) fra Oldsum $^{25}$ højlydt at indvillige $i$ det og forhindrede udbetalingen af den allerede lovede sum indtil videre. ${ }^{26}$ Allerede forinden var det kommet til tumultagtige episoder i befolkningen på grund af forskellige skatter og (krigs)afgifter; Wagen Jörgens ${ }^{27}$ fra Goting råbte oven i købet trodsigt, at han hellere ville ofre sit liv og vende sit fædreland ryggen for evigt end finde sig $i$, at noget blev taget fra ham med magt (DP 205). Endnu i 1665 blev råd- og gangfersmanden Wagen Jensen ${ }^{28}$ fra Utersum idømt en bøde på 20 rigsdaler som agitator i en »rebbelsake«. Sagen hvirvlede meget støv op og omfattede også nogle amringer. Jensen blev dømt for at have tilbageholdt de allerede indsamlede "herrengelder «, dvs. afgifterne til landsherren, som en slags håndpant (DP 1706).

Denne opsætsighed i dele af befolkningen og ikke mindst også blandt dens repræsentanter blev på ingen måde kun ytret i det skjulte, og Schack og hans efterfølgere i Ribe og Møgeltønder måtte gentagne gange kæmpe med den. Den var imidlertid ganske sikkert ikke den eneste grund til, at retsplejen på Vesterland Før og Amrum i tiltagende grad kom i de overordnede myndigheders søgelys. Snarere var det vel herredsforfatningen, der virkede gammeldags, og dens udøvende organer, som nu tydeligvis ikke mere svarede til den nye enevældige tidsånds forestillinger, især ikke dens krav om et moderne retsvæsen og en moderne forvaltning. Dertil kom, at Jyske Lovs gammeldags procesordning med edsbeviser på mange måder stod i vejen for en objektiv bedømmelse af et juridisk sagsforhold. Den var en hindring for dannelsen af den mere abstrakte retsopfattelse, der var en ganske væsentlig forudsætning for den professionalisering af jurisdiktionen, som centraladministrationen tilstræbte.

I centrum for kritikken stod udover de to kongelige (eller kortvarigt greveligt-schackenborgske) embedsmænd i Vesterherred, landfogeden og tingskriveren, især rådet $\mathrm{i}$ Vesterherred. Juridiske forkundskaber havde de tolv medlemmer af dette kollegium sædvanligvis ikke. Rollen som medlemmer af den privilegerede kaste i samfundet talte mere ved besættelsen af en rådmandsplads end faglige kvalifikationer. Dem skulle embedets indehavere erhverve sig efterhånden i den daglige retspraksis. Domsafsigelserne rettede sig vel derfor hyppigere 
efter en naturlig retsfølelse og sund menneskeforstand end efter juridisk sagkundskab. Tilsvarende ofte blev en rådsdom kasseret af appelinstansen i Viborg som fejldom, fordi den ikke var i overensstemmelse med gældende lov, og rådmændene skulle hver gang behørigt retsforfølges ifølge lovbestemmelserne. Hyppigt beskyldte de dømte i deres appelsager rådmændene for partiskhed. Når en rådmand skulle træffe en afgørelse, faldt det ham åbenbart ikke altid let at bevare den neutralitet over for parterne, som loven krævede, f.eks. ikke, når begge sider i en konflikt mellem de meget ofte vidtforgrenede føring-amringerslægter ikke alene appellerede til hans upartiskhed som dommer, men samtidig også til den solidaritet med familien, landsbyen eller egnen, han i det hele taget måtte føle sig forpligtet til som medlem af sådanne forbundne slægter, som del af bondestanden i landsbyen eller som herredsbonde. Her var et sammenstød af interesser ofte givet på forhånd. Blod er nu engang tykkere end vand.

Men også landfoged og tingskriver levede i stadig ringere grad op til deres embeders stigende krav, efter at den kongelige centralmagt efter 1660 havde giort sig meget lovende anstrengelser for at stramme forvaltningsstrukturen $i$ hele riget og bl.a. også for at professionalisere retsudøvelsen på lavere niveau. Særligt tydeligt blev det med landfoged Jap Peters. ${ }^{29}$ Han var udlært smed, og i begyndelsen var han tingskriver hos sin forgænger Erk Olufs fra Oldsum, der døde i 1651. Han blev tydeligvis kun hans efterfølger, fordi han var skrivekyndig; hans nyerhvervede embede stillede $i$ enhver henseende større krav, end han kunne honorere. En af Japs samtidige, diakonen ved St. Laurentii Paulus Flor, ${ }^{30}$ stiller ham $\mathrm{i}$ det dårligst tænkelige lys $\mathrm{i}$ et håndskrift med »Egenhændige Efterretninger ${ }^{31},{ }^{1}$ som han har efterladt sig. Jap var en hykler og rænkesmed, hedder det, en mand, som næppe
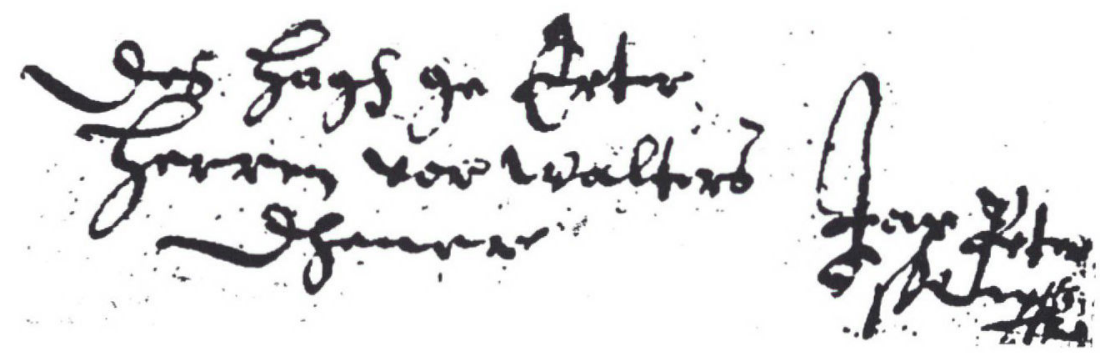

Landfoged Jap Peters' underskrift på et brev af 26. juni 1671 til godsforvalter Nicolaus Tych på Schackenborg. Landsarkivet i Aabenraa. 
nogen har respekteret, og som blev foged mod bøndernes og herredets øvrige befolknings vilje.

Faktisk er der i tingprotokollerne 1658-71 mange eksempler på, at befolkningen var viklet ind i langtrukne, plagsomme sager med Jap Peters, hvor han måtte finde sig $\mathrm{i}$ verbale trusler og ærekrænkende skældsord og i, at man ihærdigt og åbenlyst satte sig imod hans anordninger. F.eks. skærer man grimasse ad ham på offentligt tinge (DP 2057) og kaldte ham bl.a. en »hundsfot « (DP 992), »løgner « (DP 1726, 1744) og "meneder « (DP 1003), man stjal til almindelig munterhed hans nye fjertæppe fyldt med uglefjer, som han lige have ladet fremstille til herskabet (DP 663), og da han en gang ville beslaglægge en pantsat okse, lod ejeren af den, Ricklef Peters fra Goting, den senere tingskriver (se ndfr.), oven i købet en bøsse fyre af, hvorpå Jap Peters og de vurderingsmænd, der ledsagede ham, måtte drage af igen med uforrettet sag (DP 206). Også Japs evige modstander Wagen Frödden (ca. 1638-1690) fra Oldsum, med hvem han bl.a. udkæmpede en årelang, forbitret strid om benyttelse af en eng, stillede sig engang $i$ vejen for ham med våbenmagt (DP 2060). Opremsningen af sådanne tilfælde af opsætsighed og respektløshed over for landfogeden ville kunne fortsættes uden besvær. Desuden synes tingprotokollerne at bekræfte Paul Flors udsagn om, at Jap Peters har haft et for stort forbrug af alkohol. Et sted hedder det, at landfogeden allerede, før tinget begyndte, var så fuld, at han ikke kunne holde ting og kort efter var kørt hjem igen, selv om forskellige personer, der skulle være til stede på tinge, allerede havde indfundet sig (DP 1396).

Hans Schack og hans embedmænd kan i det lange løb ikke have undgået at høre om disse for alle parter uheldige forhold, for stadig oftere tog Schack sig nu personlig af en sag, der verserede ved herredsretten ${ }^{32}$ eller sendte en af sine embedsmænd som befuldmægtiget for at tale på tinge i sit navn. Også de stridende parter henvendte sig stadig oftere direkte til den højeste tilsynsførende for deres ret for at undgå en måske tidrøvende forhandling på det hjemlige ting, hvis udfald for de fleste alligevel ikke helt var til at forudse.

Hans Schacks efterfølger, lensgreve Otto Diedrich Schack, ville ligeledes modvirke disse uheldige tilstande, idet han i 1676, da Jap var gået af som landfoged, med Joachim Lütken udnævnte den første forvaltningsfagmand udefra som efterfølger, en mand som var velbevandret $i$ juridiske anliggender. Dette forsøgte en gruppe af herredsbønder omkring den indflydelsesrige rådmand Michel Jung Olufs fra 


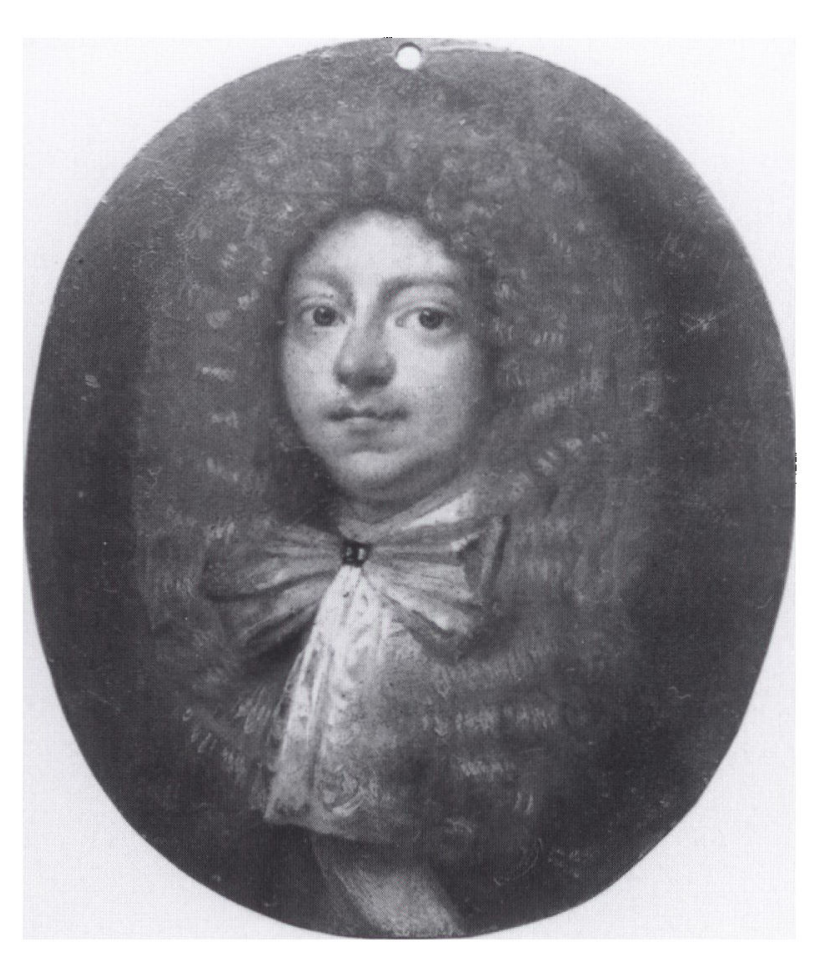

Miniatureportræt af lensgreve Otto Diedrich Schack (1652-1683). Foto: S. Bengtsson i Frederiksborgmuseet.

Goting $^{33}$ til gengæld at forpurre med alle midler. Michel var iflg. Paul Flor en rig, indbildsk bonde og træ- og humlehandler med gode forbindelser til øvrigheden. ${ }^{34}$ Han havde selv gjort sig store forhåbninger om dette embede, rejste endda i eget ærinde til Møgeltønder for at overtale grevens forvalter Nicolaus Tych til endnu en gang at vælge landfogeden ud af kredsen af bønder og rådmænd, som det havde været skik fra arilds tid. Ganske vist lå retten til at udnævne på den tid hos greve Otto $\mathrm{D}$. Schack på samme måde som den tidligere havde ligget hos lens- eller amtmændene i Ribe, men hidtil havde man altid taget hensyn til bøndernes forslag af kandidater og som regel også udnævnt dem, de ønskede. Bønderne var jo trods alt den herskende politiske klasse i samfundet i Vesterherred, og lensmanden kunne ikke lade hånt om deres interesser, hvis han ville vide sin egen og sin kongelige lensherres autoritet sikret. Der kom imidlertid ikke noget ud af Michels initiativ, for også i kontorerne på Schackenborg var de nye absolutistiske vinde begyndt at blæse, så at man dér ikke mere 
kunne lægge øre til ønsker fra en lille traditionsbunden og desuden oligarkisk præget interessegruppe.

\section{Striden Matz Peters/Hans Eggebeck}

Selv da Vesterherred i begyndelsen af 1683 igen kom under den kongelige administration i Ribe, og man den 16. juli 1684 med Hans Eggebeck $^{35}$, som stammede fra Sonderborg, igen udnævnte en embedsmand udefra til deres landfoged, lykkedes det ikke afgørende at forbedre retsforholdene på Vesterland Før og Amrum. Også Eggebeck vakte snart anstød. Det skete, da han på herredstinget lod sig forlede til en ærerørig udtalelse mod Matz Peters ${ }^{36}$ fra Oldsum på Før, hvis indhold han tilsyneladende ikke kunne bevise. Han blev nu selv sagsøgt af Matz Peters på højere sted - med succes, som det fremgår af kildeteksterne, der er overleveret i Ribe amtsarkiv. Landsretsråderne i Viborg bestemte, at fogeden Eggebeck på offentligt tinge skulle gøre behørig afbigt over for sin modstander. Det nægtede han imidlertid stædigt, trods gentagne stadigt skarpere trusler om straf. Til sidst forsøgte han forgæves at blive benådet $\mathrm{i}$ denne sag af kongen og Højesteret.

I grønlandskommandøren Matz Peters, der både var en verdensmand og velhavende, havde Eggebeck fundet en drøj og ubekvem modstander, som han helt sikkert ikke kunne klare. Matz hørte til søfartens mest fremtrædende personligheder på den tid, med anseelse langt ud over den snævre hjemstavn i havnebyerne langs Nordsøen. Alt tyder på, at Matz meget vel var klar over sin fremtrædende sociale og økonomiske stilling blandt vesterlandføringerne og også viste dette udadtil. Som de fleste sømænd fra de nordfrisiske øer gav han sit traditionelle frisiske navn en nedertysk eller nederlandsk form, når han var i tjeneste udenlands, og derfor blev Matz Peters her til Matthias Petersen eller Pietersen. Det er karakteristisk, at han ikke aflagde den fremmede navneform hjemme. Formodentlig anså han den for mere mondæn og bedre passende til hans position. Da han døde den 26. september 1706, købte hans arvinger - for den klækkelige sum af 100 rigsdaler - af kirkeværgerne i St. Laurentii sogn tilsagn om at måtte begrave ham foran alteret i St. Laurentii kirke, hvilket også skete. Dette privilegium var til dato kun blevet tilstået nogle få, udvalgte præster, men til sidst dog også en lægmand, Matz' svoger Johan Flor. Næsten 14 år senere kom det dog til et sammenstød, da 


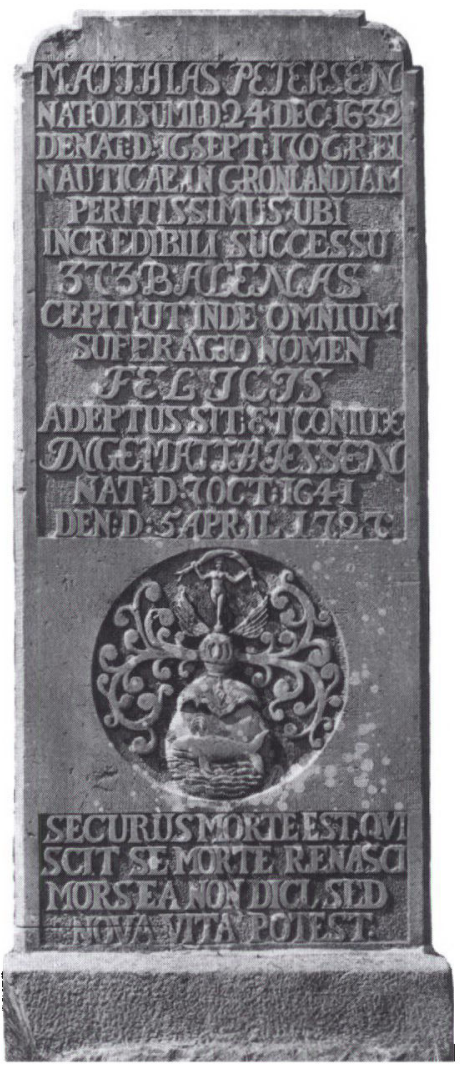

Gravsten over Grønlandskommandøren Matz Peters ved St. Laurentius-kirken i Süderende på Før. Foto: W. Lüden $i$ Ferring Stiftung, Alkersum.

de efterlevende fortsat nægtede at betale de lovede 100 rigsdaler med renter. Derpå blev Matz uden videre gravet op igen og flyttet fra apsis til kirkegården ${ }^{37}$, hvor hans imposante ligsten, der i begyndelsen vel har ligget som gravplade foran alteret, endnu i dag kan ses syd for kirken. Men om det så er dens oprindelige plads, får stå hen i det uvisse.

Forud for disse fornærmelser post mortem var imidlertid gået mangeårige stridigheder og fjendtligheder mellem Matz og talrige personer i sognet, især med bønderne i rækkebyen Oldsum-KlintumToftum. Fra omkring 1694 havde han f.eks. ligget i strid med græsningsinteressenterne dér om udligningsbetaling for ekstra græsningskvoter (på Før-frisisk beltring), som han havde gjort krav på. På trods af at den fælles benyttelse af landsbyens engarealer blev reguleret af 
gamle, men muligvis ikke nedskrevne overenskomster mellem bønderne (Beliebungen), ville Matz ikke acceptere de aftaler, bønderne havde truffet, og bragte sagen for herredsretten. Rådets dom faldt dog ikke ud til hans fordel, hvorpå Matz ankede til landsretten i Viborg, hvor han til sidst sejrede. ${ }^{38}$ Måske havde han faktisk retten på sin side, men det kan også være, det var lykkedes ham at vinde landsretten for sig ved hjælp af smidig lobbyvirksomhed. Også i andre retssager - og dem var der mange af - oplever vi Matz som en selvbevidst og yderst stridbar advokat for egen sag, som forstod ubøjeligt at sætte sine egne interesser igennem over for enhver på trods af enhver modstand. Han skånede ikke engang nære slægtninge som f.eks. sin svoger, grønlandskommandøren Johan Flor fra Oldsum, ${ }^{39}$ ja, selv ikke socialt svagere, som den gamle, dybt forgældede enke Trinke Jannen, ${ }^{40}$ og han sparede dem end ikke for nærmest smålige sager, som det efter nutidens målestok ikke ville være umagen værd at rejse. Den omstændighed, at det her var "en af de store " der ikke viste den lokale retsorden i skikkelse af herredsretten og andre juridiske forsamlinger nogen respekt, eller i hvert fald ikke ret megen, og i stedet havde for vane at søge at få ret ved højere instanser - og sædvanligvis også fik det, det kan ikke kun have vakt vrede hos de umiddelbart ramte, men må i stigende grad have vakt uvilje også blandt de øvrige indbyggere i herredet. I 1800-og endnu mere i 1900årene er Matz Peters jævnligt blevet fremstillet som en heroisk førerpersonlighed, som skal have haft en vigtig funktion som forbillede for søfolkene på de nordfrisiske øer. Det kan der i hvert fald kun $\mathrm{i}$ begrænset omfang være tale om, mens han levede. At mange søgte at leve op til ham i deres personlige stræben efter succes og materiel velstand, kan være rigtigt nok. Men der har nok kun været få, der virkelig elskede og ærede ham, for dertil gav han i sandhed ikke sine medmennesker nogen lejlighed, allermindst på sin egen hjemegn. Mange har sikkert følt et inderligt had over for ham, og ikke bare af social misundelse.

I denne situation opstod der et ubrydeligt sammenhold mellem rådmændene, tingskriveren og landfoged Hans Eggebeck, som i mellemtiden påny havde trukket det korte strå i en landsretssag mod Matz Peters, hvor det drejede sig om beslaglæggelsen af et skib. ${ }^{41}$ Men heller ikke $\mathrm{i}$ denne trepartsalliance formåede de at gøre noget mod deres ærkemodstander, da stiftamtmanden i Ribe Franz Eberhard von Speckhan demonstrativt stillede sig på Matz' side. Denne 
beslutning må være faldet stiftamtmanden så meget lettere, som Ricklef Peters fra Goting, der i mange år havde været tingskriver, i en kontrovers med Matz begik den letsindige fejl at forfalske et tingsvidne til fordel for fogeden Eggebeck og rådmændene. ${ }^{42}$ Det var efter gældende dansk lov en tungtvejende forseelse, og stiftamtmanden reagerede prompte. Ricklef blev indtil videre suspenderet fra sit embede, og der blev udnævnt en kommissarisk foged (på ældre dansk setteschrifuer) ved navn Hans Matthiesen fra Nieblum. ${ }^{43}$ Men Ricklef skal ikke alene have forfalsket et tingsvidne, men også i strid med kongelig forordning have skrevet på "ustemplet papir «. I begyndelsen gjorde de forholdsregler, der blev truffet mod Ricklef, kun ringe indtryk på ham. For som Matz Peters berettede til stiftamtmanden, skal Ricklef også fortsat have udøvet sit embede og endog engang have givet sig af med at afsige domme i stedet for landfoged Eggebeck, hvad der ifølge loven var groft embedsmisbrug.

Men landfoged Eggebeck gjorde det heller ikke let for sine modstandere. Ikke alene nægtede han lige som tidligere hårdnakket at gøre tilbørlig afbigt over for Matz på offentligt tinge (se ovfr.), han dristede sig også til skriftligt at forbyde de otte neutrale skønsmænd, som stiftamtmanden havde indsat, at befatte sig med den omstridte græsningsret og gennemføre en regelret afregning mellem Matz og bønderne i rækkebyen. ${ }^{44}$ Ville han bare vinde tid med det for at afvende et truende nederlag, eller havde han en mistanke om, at en mere indgående undersøgelse af sagsforholdet ved de otte upartiske mænd ville bringe yderligere uregelmæssigheder for dagen, og at det ikke ville være til hans fordel? Var det måske bønderne i rækkebyen eller måske endda rådet, der havde nødet ham til det, fordi de frygtede noget lignende? Eggebeck var ikke mindst afhængig af bønderne, da han havde stor gæld til i hvert fald en af dem, Jung Rörd Matzen, der stammede fra Oldsum, og ikke var i stand til at tilbagebetale den rettidigt til den tid, der var aftalt.

\section{Nyordningen}

I hvert fald fik Eggebeck med denne overskridelse af sin embedsmyndighed definitivt bægeret til at flyde over, så meget mere som han på den måde med vilje havde sinket rettens gang i over to år. I denne situation må stiftamtmand von Speckhan være blevet klar over, at en væsentlig årsag til de stadige plagerier med hensyn til retsudøvelsen 
Franz Eberhard von Speckhan (1628-1697), stiftamtmand $i$ Ribe. Maleri på Ribe rådhus. Foto: A. Brandt. Frederiksborgmuseet.

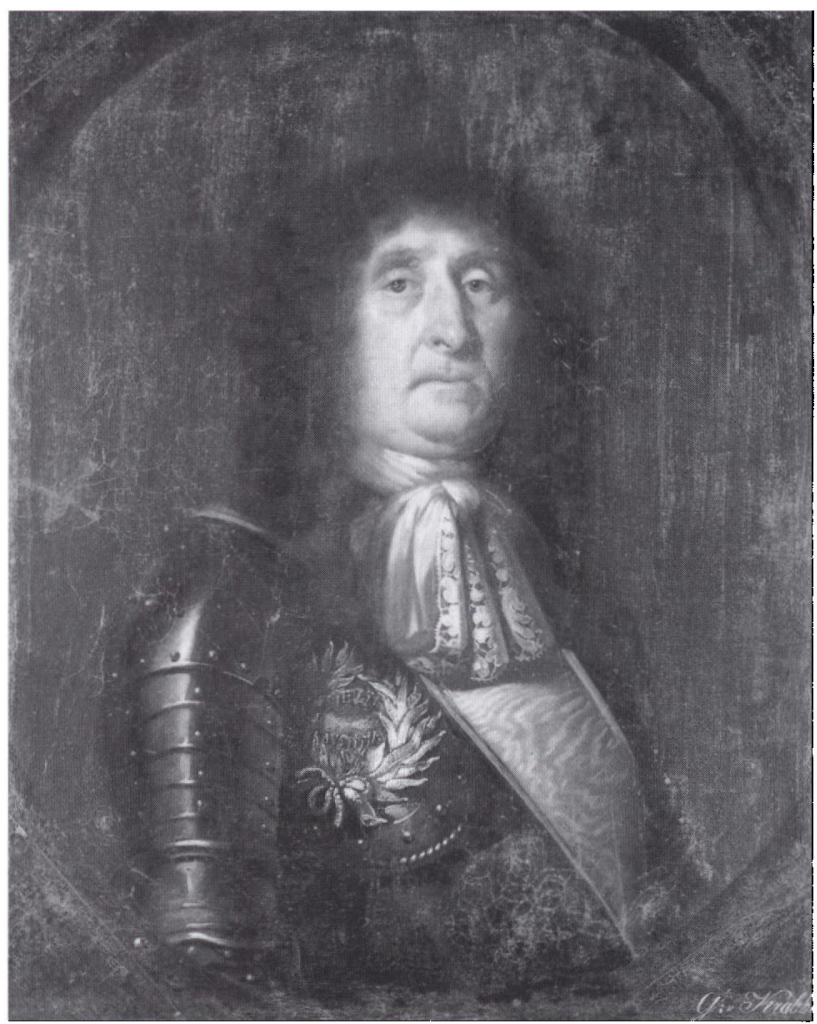

på Vesterland Før og Amrum lå $\mathrm{i}$ herredsrådet som institution, og at en effektiv afhjælpning af disse uheldige tilstande bedst kunne ske ved at ophæve rådet. Utvivlsomt kan mange af rådets medlemmer have været hæderlige mænd, hvis ord havde vægt $i$ befolkningen, men hæderlighed alene og evnen til at repræsentere kan ikke erstatte juridisk sagkundskab, som især efter de store statsretslige omvæltninger og reformer efter 1661 var nødvendige i Danmark. For så vidt var afskaffelsen af rådet derfor kun en logisk konsekvens. I en kongelig ordre af 27. februar 1697 fulgte Danske Kancelli stiftamtmandens memoriale af 18. februar 1696, hvori det blev foreslået at lægge domsmyndigheden $\mathrm{i}$ hænderne på en tingfoged og i stedet for rådet udnævne otte stokkemænd, ${ }^{45}$ hvis eneste opgave det skulle være at være vidner til forløbet af tinget.

Stiftamtmanden vækker i sin betænkning det indtryk, at Danske Lovs ånd og bogstav endelig ville komme til sin ret takket være ind- 
sættelsen af en tingfoged og de otte stokkemænd. Noget virkelig nyt medførte denne ordning imidlertid ikke, for allerede under Jyske Lov hørte det mange steder for længst til almindelig retspraksis, at det kun var fogeden, der havde beføjelse til at afsige domme. Ganske vist var der derudover stadig herreder, hvor der lige som på Vesterland Før og Amrum var bevaret en ældre retsordning, som endnu stod de oprindelige bestemmelser i Jyske Lov nærmere, og ifølge hvilken en herredsfoged kun skulle lede tingmødet og ellers afholde sig fra enhver domsafsigelse, da denne var forbeholdt forskellige dømmende forsamlinger. I Vesterherred var det som nævnt helt overvejende rådet, ransnævningene og sandemændene. Det var heller ikke nogen hidtil ukendt retsforsamling, der dukkede op på arenaen med de otte stokkemænd. Tværtimod fortsætter stokkemændene direkte den tradition for tinghørere, som der er vidnesbyrd om i Jyske Lov. De kaldes i tingprotokollerne fra Før Vesterherred og Amrum gennemgående tingvidner (mnty. dingtügen) og blev fra tingtermin til tingtermin nyudnævnt blandt bønderne ved en ikke nærmere specificeret fremgangsmåde, hvorimod den kongelige ordre af 27. februar 1697 fastsætter en månedlig rotation. De otte tingvidners opgave bestod lige som stokkemændenes kun $\mathrm{i}$ at bevidne tingets forløb og eventuelt aflægge ed. De havde heller ikke nogen dømmende funktion. Yderligere må forsamlingen af sandemænd, som dømte i meget grove forbrydelser som mord, drab eller andre svære legemsbeskadigelser, være forblevet mere eller mindre uantastet i deres embede, medens ransnævningene, der var det organ, hvorunder sager om tyveri og røveri sorterede ${ }^{46}$ formodentlig delte skæbne med herredsrådet og blev afskaffet, selv om kildeteksterne i Ribe Amtsarkiv og Jyske Registre ikke nævner sandemændene og ransnævningene med et eneste ord. Sluttelig ser herredsbønderne heller ikke ud til at være sluppet uberørt. Bønderne, dvs. de frie hus- og grundejere, der ikke stod i noget afhængighedsforhold, og som var ejere af et helt bol, havde som nævnt til dato et vigtigt ord at sige i Vesterherreds skatte- og økonomisager. Nu var det tydeligvis forbi med det. Ganske vist blev alt skattepligtigt gods i Vesterherred også herefter med nogle års mellemrum takseret af de 24 hegnssynsmænd (Ummärkungsmänner), hvorefter nogle af dem, regnskabsmændene (Rechensmänner), beregnede skattesummen efter de registrerede formueværdier og fordelte den på de 40 skatteområder (Gangferen) på Vesterland Før og Amrum, så at forstanderne for disse områder, gangfersmændene, til sidst kunne indsamle skatterne, ${ }^{47}$ men 
dertil krævedes ikke længere bøndernes godkendelse; godkendelsen af de forelagte skattelister var nu alene stiftamtmandens sag.

Da rådet blev afskaffet og magten dermed taget fra bønderne, ændredes samtidig fogedens status på tingmødet og i tingsretten. Hidtil havde han som øvrighedens repræsentant helt overvejende varetaget statens interesser. Først og fremmest ved, at han formelt åbnede tinget og ledede forløbet, forlenede han enhver handling på tinget med den nødvendige legitimitet, dog uden selv direkte at påvirke arbejdet med at nå til en afgørelse eller selve domsafsigelsen i den enkelte sag. Men efter at den lokale jurisdiktion, der tidligere havde ligget hos de lokale bønder eller de dømmende udvalg, som de havde besat, var blevet overdraget til ham på stiftamtmandens foranledning, udgik fra 1697 al administrativ og juridisk magt fra ham som birkefoged, i det mindste på birkeniveau, dog bortset fra de forskellige særtilfælde, hvor befolkningen lige som tidligere havde ret til at ytre sig, som f.eks. forvaltningen af diget på Vesterland Før, ved den ovenfor skildrede fordeling af skatter og afgifter på gangferene og ved sandemændenes domfældelse af meget grove forbrydere. Forfatningsmæssigt set var herredstinget dermed ikke længere et redskab for herredets indbyggere eller konkret udtrykt en slags folkeforsamling, hvor folkets repræsentanter, bønderne, havde indflydelse på områdets kommunale interesser og udøvelsen af den dømmende myndighed. Tværtimod blev tinget nu en af den enevældige herskers institutioner, hvor hans forlængede arm, birkefogeden, som han personlig havde udnævnt, fremover udgjorde den centrale magtfaktor i alle vigtige offentlige sager. Bønderne havde nu - som alle andre kongelige undersåtter i Vesterherred Før og på Amrum - kun en rolle som statister.

Der var således gået 36 år efter at Frederik 3. havde underskrevet Enevoldsarveregeringsakten af 10. januar 1661 og 14 år efter indførelsen af Danske Lov i efteråret 1683, før Vesterherred lokalt - $\mathrm{i}$ alt fald på forordningsniveau - mærkede det strukturelle skifte fra et feudalsamfund, der endnu virkede senmiddelalderligt, til den tidligt moderne stat med præg af enevælden. At denne forandring har vakt begejstring på Før er nok tvivlsomt. Man spørger sig selv, om den kongerigske enklave Vesterland Før og Amrum på grund af sin afsides beliggenhed, dvs. i det daværende danske riges sydligste udkant, muligvis netop var kommet lidt uden for synsfeltet for centraladministrationen i København og så længe uforstyrret kunne fortsætte sit eget liv $i$ afsondrethed. 
Men det er måske alligevel ikke helt tilfældet, for allerede i 1687 indberettede landsretsråderne i Viborg til kongen om de særlige, i deres øjne usædvanlige retsforhold på Vesterland Før og Amrum. Det hedder på s. 81 i deres betænkning: "Anlangendes Vesterlands Føer, saa haver denne Insul hidindtil haft Retten holdet paa en sær Maade og det ved 8te [recte: 12] Raadmænd og en Skriver, dog appeleres derfra til Landstinget, Mens som vi og [recte: om] disse Stæders Situation og Beskaffenhed ingen vis Underretning haver kunnet erholde, saa haver vi ingen udførligere Relation Eders Majestæt derom denne Gang kunnet tilstille. ${ }^{48}$

Endelig er det uvist, om Matz Peters gjorde sig rækkevidden af sine klagebreve til stiftamtmand von Speckhan klar. Amtmanden tog dem jo som en - muligvis velkommen - anledning til at indlede en retssag mod landfoged Eggebeck, tingskriver Ricklef Peters og medlemmerne af herredsrådet med det erklærede mål helt at afskaffe rådet. Måske drejede det sig for Matz i første række kun om at få oprejsning for en uret, han (formentlig) havde lidt, altså om en helt personlig hævnakt, som lige så vel kunne være vendt mod bønderne i rækkebyen, hvortil Matz typisk nok ikke hørte. Følte Matz sig ikke respekteret og agtet af bønderne i det omfang, som han på grund af sin fremtrædende stilling i samfundet mente at kunne gøre krav på? Måske stak der dog alligevel mere under. Det er nemlig påfaldende, at Matz af en lægmand at være havde et forbavsende godt kendskab til jura og var god til at handle taktisk og behændigt. Var det måske hans søn Peter Matthiesen, ${ }^{49}$ der studerede jura i Halle, der hjalp ham? Tjente faderens fortsatte angreb på foged og råd bl.a. til i god tid at gøre sønnen til samtaleemne hos øvrigheden, når en nybesættelse af embedet som birkefoged $i$ en ikke alt for fjern fremtid blev aktuel? Faktisk blev Peter Matthiesen i 1713 udnævnt til landfoged over Østerland Før og Sild og samtidig til herredsfoged i Wyk på Før med hovedsæde i Nieblum. ${ }^{50}$

\section{Følgerne}

Da kong Christian 5. den 27. februar 1697 udnævnte Hermann Papke fra Haderslev til ny birkefoged over Vesterland Før og Amrum, ${ }^{51}$ og denne i sin troskabsed til kongen bl.a. havde svoret »med al Kraft og Formue derhen mine Tanker og Idrætter at dirigere, at Hans Kongl: Maj: absolutum Dominium, Souverainitet og Arve-Rettighed over 
Hans Kongl: Maj: Kongeriger og Lande Uforanderlig conserveret og paa Hans Kongl: Maj: retmæssige Arve-Successor fortsat og forplantet vorde«, betød det afslutningen for Vesterland Før og Amrums gamle herredsforfatning og dermed for et stykke af øernes nedarvede selvstyre, der endnu havde bevaret middelalderlige træk, og som gennem århundrederne havde udviklet sig under Jyske Lov. Nu blev denne gamle regionalret afløst af Danske Lov, den af den enevældige konge givne og i hele kongeriget gældende enhedslov. I fortiden havde ikke mindst manglende danskkundskaber blandt rådmændene og medlemmerne af de andre dømmende forsamlinger vanskeliggjort og forhindret brugen af Danske Lov i Vesterherred. Nu skulle man ikke længere tage hensyn til den slags problemer, for herefter blev retsplejen alene varetaget af birkefogeden, og det blev fra da af forudsat, at han i tilstrækkelig grad beherskede det danske embedssprog.

Hvordan de mennesker, der på den tid levede på Vesterland Før og Amrum, har bedømt de reformer, der blev indledt omkring 1697, det er der ikke overleveret noget om. Når man betænker, at de fleste føringer og amringer var konservativt indstillede og dybt skeptiske over for enhver form for fornyelser indført af fremmede, må vi dog antage, at foranstaltningerne dengang næppe er blevet mødt med særlig varme følelser, heller ikke, selv om de objektivt betragtet har betydet en forbedring af de bestående forhold.

\section{ARKIVMATERIALE}

Föhrer Inselarchiv (for tiden i Kreisarchiv Husum): Westerlandföhrer und Amrumer Ummärkungsprotokolle 1755-1805, A 3/829.

Landesarchiv Schleswig-Holstein: Urkunden zur Geschichte Westerlandföhrs und Amrums, Abt. 400.5, Nr. 331.

Landsarkivet for Senderjylland, Aabenraa: Justitsprotokoller Vesterland-Før og Amrum Birk 1732-1822, bd. 1-8.

Ribe Bispearkiv 1575-1765, Nr. 7, capsa 18 , pakke 4, St. Laurentii.

Landsarkivet for Norrejylland, Viborg: Ribe Amtsarkiv, Kopibog B 9-11.

Rigsarkizet, Kobenhaun: Danske Kancelli, Jyske Registre 1695-99.
Danske Kancelli, Jyske Tegnelser 169799.

Universitätsbibliothek Kiel: Pauli Flor Eigenhændige Nachrichten, Cod. M.S.S.H. 227.

\section{FORKORTELSER}

DBL: Dansk Biografisk Leksikon, bd. 1-16.

DL: Danske Lov af 1683, cit. efter S. Iuul 1949.

DP: Dingprotokolle der Westerharde Föhr und Amrum 1658-1671, Bd. 1-2, udg. af V. Faltings 1990-92; de angivne tal henviser til afsnitsnumre.

GRJ: Geschlechter-Reihen St. Johannis/Föhr [ms. i Ferring Stiftung i Alkersum på 
Föhr]. De angivne tal henviser til den nævnte persons personlige slægtsnummer.

GRL: Braren, L. 1949-50. Geschlechter-Reihen St.Laurentii-Föhr. De angivne tal henviser til den nævnte persons personlige slægtsnummer.

JL: Jyske Lov af 1241, citeret efter den nedertyske Ekenberg-oversættelse 1593 i N. Falcks udgave 1819.

SHBL: Biographisches Lexikon für SchleswigHolstein und Lübeck, bd. 1-11.

\section{NOTER}

1. Jfr. V. Faltings: Was ist ein "Gangfersmann«?, i: Nordfriesisches Jahrbuch N.F. 18-19, 1983, s. 273, note 13-15.

2. Den danske juridiske term birk har siden slutningen af middelalderen betegnet et udskilt retsområde, der ofte enten slet ikke eller også kun delvis horte under den almindelige herredsinddeling og bestemmelserne $i$ den på den tid gæeldende landskabslov; jfr. Poul Johs. Jorgensen: Dansk Retshistorie, 1947, s. 391, 409, 508-10.

3. Ocke Nerong: Die Insel Föhr, 1903, s. $85 f$.

4. C.P. Hansen: Chronik der Friesischen Uthlande, $1877 / 1977$, s. 162.

5. Kopibog i Ribe Stiftsarkiv B 9-11 i Landsarkivet for Nørrejylland i Viborg og Jyske Registre 1695-99 i Danske Kancelli i Rigsarkivet i Kobenhavn. Kildeteksterne er trykt i Nordfriesisches Jahrbuch 37, 2001, s. 41ff.

6. Ribe Stiftsarkiv, B 9-11, s. 45ff.

7. Jyske Registre 1695-99, fol. 192v.

8. Om de kongerigske enklaver jfr. $M$. H. Nielsen: De kongerigske enklaver, i: Fra Ribe amt bd. 5, 1919-22, s. 485ff. - I enklaverne på fastlandet $L \boldsymbol{g}$ herred, Ballum og Møgeltender birk var de administrative og juridiske forhold ret indviklede på grund af det meget strøgods. Det havde bl.a. til følge, at beboerne inden for ét og samme sogn, ja selv inden for én landsby kunne være tingpligtige til forskellige ting. En god oversigt giver F. Gribsvad og J. Hvidtfeldt: Landsarkivet for de sonderjyske Landsdele. Vejledende arkivregistraturer bd. 6,1944 , s. $82 \mathrm{ff}$.; jfr. desuden L. Andresen: Von der schleswigschen Amtsverwaltung zur preußischen Kreisverwaltung in Tondern, i: Festgabe Anton Schifferer zum 60. Geburtstag, 1931, s. 160-239.

9. Efter at Hans Schack var trådt i dansk tjeneste og var blevet naturaliseret som dansk adelig, hvad der dog $\mathrm{i}$ begyndelsen var forbundet med vanskeligheder, ventede der ham en lodret militær og politisk karriere: 1658 generalløjtnant til hest og til fods og oberst i Skånske Fodregiment, samme år chef for Dronningens Livregiment og guvernør for København, 1659 feltmarskal, efter freden i København i 1660 overstkommanderende for den danske hær, samme år medlem af Rigsrådet, præsident for Krigskollegiet og assessor i Statskollegiet, samtidig udnævnelse til rigsfeltherre, 1663 ridder af Elefanten, 1670 medlem af Gehejmerådet, 1671 ophøjelse i grevestanden og ridder af Danebrog.

10. L. Bobé, G. Graae et al.: Danske len, 1916, s. 89f. P.K. Iversen: Herremand og bonde i Vestslesvig, i: SjyÅrb 1942 s. 58 ff.., DBL bd. 13 s. 16 og SHBL 7, s. $258 \mathrm{f}$.

11. En afskrift af det af Frederik 3. udstedte skøde af 5 . september 1661 findes i Landesarchiv SchleswigHolstein, Abt. 400.5 Nr. 331, s. 25f; jfr. desuden Kronens Skoder 1908, s. 102ff., L. Bobé, G. Graae et al. 1916, s. 89, og Iversen 1942, s 59.

12. Inden for For Vesterherred og Amrums områder drev Schack østersfangst på ikke mindre end syv østersbanker: 1. "Das Gosewater « nord for Før, 2. "Lehnsand binnen der Rewel « og 3. "Lehnsand buten der Rewel" nordvest for For samt 4. "Nybelum Ufer" syd for Nieblum, 5. "Nord-Westen Amrum«, 6. "Amrum Hafen" og 7. "Schmaltiefkante" syd for Amrum. At østersfiskeriet havde stor økonomisk betydning, kan man se af, at det $i$ samtidige kilder betegnes som "grevskabets smukkeste klenodie«; jfr. H.C. Davidsen: Grevskabet Schackenborgs østersfiskeri, i: SjyMskr. 1955, s. 6-13, og H.K. Kristensen: Om Vesterland-Før og Amrums tilhørsforhold, i: 
Sjy Årb. 1974, s. 43, samt DP 1094, 1106, $1161,1661,1714$ og 2126, desuden L. Andresen: Von schleswigschen Austernbänken im 16. und 17. Jahrhundert, i: Die Heimat 37, 1927 s. 77f. Forskellige kort, der viser beliggenheden af de nordlige kongelige og Schackske ostersbanker mellem Ballum og List, findes i Landsarkivet i Aabenraa. Mht. beliggenheden af de hertugelig-gottorpske vstersbanker, jfr. J. E. Randahls kort fra 1744, Landesarchiv SchleswigHolstein, Abt. 402 B II Nr. 231; en noget mindre detaljeret kopi af det fra 1797 ligger i Landsarkivet i Aabenraa. - Om de talrige fiskegærder, som indbyggerne i Vesterherred havde opstillet i Vadehavet nær ved kysten (jfr. f.eks. DP $2268,2279,2684$ ), også var afgiftspligtige til Schack, kan ikke ses af tingprotokollen 1658-71. Hvad jagten på småvildt angår, ser det ud til, at Schack $\mathrm{i}$ Vesterherred $i$ det mindste har benyttet rettighederne til harejagten (jfr. DP $1302,2120,2546)$, selv om det måske også har drejet sig om jagten på andre vilde dyr (jfr. DP 2546). Muligvis tilkom indkomsten af fangsten af vildænder med slagnet ham også (jfr. f.eks. DP 2158, 2171).

13. En afskrift af det af Frederik 3. udstedte skøde af 1 . november 1661 findes i Landesarchiv SchleswigHolstein, Abt. 400.5, Nr. 331, s. 26 . Også jus patronatus af Ballum, Mogeltønder og den sydlige del af Rømø gik ved denne lejlighed til Schack, jfr. Kronens Skoder 1908, s. 110, L. Bobé, G. Graae et al. 1916, s. 89 f. og P.K. Iversen 1942, s. $58 \mathrm{f}$.

14. Jfr. DP 2198, 2484, 2508.

15. Det ses af Schacks bestemmelser af 22. juli 1662 og 20. marts 1665, begge i afskrift i Landesarchiv SchleswigHolstein, Abt. 400.5, Nr. 331, s. 2ff. og $4 \mathrm{ff}$.

16. Oprettelsesbrevet er gengivet i uddrag hos L. Bobé, G. Graae et. al: Danske Len, 1916, s. 91f. Til et grevskabs privilegier hørte ifølge kongelig forordning af 25 . maj 1671 i det væsentlige følgende rettigheder: udøvelse af halsretten, kaldsret ( $j u s$ vocandi) og birkeretten, jagt- og strandretten samt retten til at inddrive boder og forbrudt gods og til at gennemføre arvedelinger.

17. Jfr. Justitsprotokoller Vesterland-Far og Amrum Birk 1732-1823, bd. 3 (174248), fol. 161v, Landsarkivet i Aabenraa.

18. Jfr. Justitsprotokoller Vesterland-For og Amrum Birk 1732-1822, bd. 4 (174959), fol. 17r, Landsarkivet i Aabenraa.

19. Jfr. V. Faltings, Die Dingprotokolle der Vesterharde Föhr und Amrum 1658-1671, 1990-92, 1 s. 11f.

20. Vedr. retslivet $i$ Vesterherred på tingprotokollemes tid 1658-71 se især V. Faltings 1990-92, 1 s. 11ff. og Faltings: Aus den Dingprotokollen der Westerharde Föhr und Amrum, i: Zwischen Eider und Wiedau, Heimatkalender für Nordfriesland, 1998, s. $41 \mathrm{ff}$.

21. Regulativet for gangfersmændene af 14. august 1750 , hvor deres opgaver for forste gang er beskrevet officielt, er trykt hos Faltings 1983, s. $276 f$.

22. I afskrift i Landesarchiv SchleswigHolstein, Abt. 400.5 , Nr. 331, s. 27f.; jfr. desuden Kronens Skoder 1908, s. $513 \mathrm{f}$.

23. I 1665 og især i 1669 rydder f.eks. amringerne Schacks østersbanker syd for Før, til trods for, at der var udstedt forbud mod det; jfr. DP 1730, 2304, 2327, 2330f., 2333 og Faltings 1998, s. 46.

24. F.eks. i 1662 bliver strandfogederne bemyndiget til at beslaglægge et spand heste med bortførte marksten og give gerningsmændene en bøde på 10 rigsdaler. Den, der fjernede så meget som én af de sten, der fastholdt den ydre skråning af diget, skulle bøde for det med 100 rigsdaler; jfr. DP 1139, 1161, 2548 og Faltings $1998 \mathrm{~s}$. $44 \mathrm{f}$.

25. GRL 159; han må ikke forveksles med sin navnebroder Rörd Olufs, der også boede i Oldsum, GRL 125.

26. Jfr. DP 282, 289, 335f., 339, 362 og 385 , desuden Faltings 1998, s. 43f.

27. Jfr. GRJ 2203. - Wagen Jörgens træffer man senere som rådmand $i$ Vesterherred.

28. Jfr. GRL 601.

29. Jfr. GRL 194.

30. Paulus Flor er en søn af præsten ved 
St. Clement på Amrum Martinus Flor (1597-1686); jfr. Arends: Gejstligheden i Slesvig og Holsten fra reformationen til 1864, 1932, 1 s. 253f. samt GRL 403 og F 227,4.

31. Universitätsbibliothek Kiel, Cod. MS. S.H. 227 [s. 10].

32. Jfr. f.eks. DP 1573, 1699, 1759, 1879, 2081, 2121, 2197, 2255, 2564.

33. Jfr. GRJ 2705,2 .

34. Jfr. Pauli Flor Eigenhændige Nachrichten [s. 12], Universitätsbibliothek Kiel, Cod. MS. S.H. 227.

35. P. Flor giver en lidet smigrende bedommelse af Eggebeck i sine "Eigenhændige Nachrichten " [s. 12], Universitätsbibliothek Kiel, Cod. MS. S. H. 227.

36. Om Matz Peters se SHBL 4, s. $187 \mathrm{ff}$.

37. De nærmere omstændigheder ved denne ikke helt dagligdags hændelse oplyses af et brev fra kirkeværgerne ved St. Laurentii til stiftamtmanden og biskoppen i Ribe; jfr. Ribe Bispearkiv 1575-1765, Nr. 7, capsa 18 , pakke 4, St. Laurentii Vesterland-Før, i Landsarkivet i Aabenraa [benyttet i fotokopi i Archiv der Ferring Stiftung i Alkersum på Før].

38. Ribe amtsarkiv, B 9-11 s. $29 \mathrm{ff}$ og $45 \mathrm{ff}$.

39. Jfr. DP 2582, 2628, 2634. - Om Johan Flor, en søn af Amrum-præsten Martinus Flor, jfr. GRL 137 og F 227,7. Johan blev i ovrigt i 1683 begravet foran alteret i St. Laurentii kirke af sin bror, diakonen i Süderende, Paulus Flor (jfr. ovenfor).

40. Jfr. DP 2654, 2769. - Om Trinke Jannen fra Oldsum, en datter af diakonen i Süderende Johannes Stillenius, jfr. GRL 163.

41. Ribe Amtsarkiv, B 9-11, s. 29 og 107.

42. Ribe Amtsarkiv, B 9-11, s. 31.

43. Om Hans Matthiesen jfr. GRJ 2390. I 1683 dukker han op i Nieblum som brygger og farver; han tilhorer ikke nogen af de familier, der hører hjemme på Før, og må være tilflyttet udefra. Måske har man valgt ham til skriverembedet af netop denne grund. En anden mulig årsag er, at han kan have behersket det danske sprog, hvad stiftamtmand F.E. von Speckhan i sin memoriale (jfr. note 5) forudsætter af en kongelig tingskriver eller $i$ det mindste betragter som ønskeligt.

44. Ribe Amtsarkiv, B 9-11, s. 29 og 45ff.

45. Om stokkemændene jfr. DL I, 7:1-4. Stokkemændene har deres navn efter de stokke eller planker, som de sidder på på tinge. Tingstedet var oprindelig en forholdsvis lille, firkantet plads, der blev afgrænset af fire store marksten, hvorover der lå planker, så det dannede en firkant; jfr. P.J. Jørgensen: Dansk Retshistorie, 1947, s. 244, og Håndbog for danske lokalhistorikere, 1952-56, s. 461.

46. Om ransneffninge generelt P.J. Jørgensen: Begreberne Tyveri og Ran i de danske landskabslove, i: Festskrift til Vinding Kruse, 1940, s. 155ff. - Den juridiske term Ransneffning betyder ordret 'rovudnævnt', en sammensætning af gammeldansk ran 'rov, plyndring' og næfning 'udnæunt', til næfne, 'kalde, nævne, udnævne'.

47. Jfr. V. Faltings 1983 , s. 260f., B.C. Roeloffs: Von der Seefahrt zur Landwirtschaft, 1984, s. 73ff. og E. Riewerts/B.C. Roeloffs: Föhrer Grönlandfahrer, 1996, s. 249ff., desuden O. Nerong 1903 , s. $119 f$.

48. Denne betænkning er trykt hos M. Lebech: Jyllands gamle Retskredse. Jyske Samlinger 5. rk. bd. 2, 1936, s. $181 \mathrm{ff}$, jvfr. især s. 222.

49. GRL 146, 5 og GRJ 2328,5 .

50. Jfr. O. Nerong 1903, s. $102 f$.

51. Jyske Registre 1695-99, fol. 192v. 